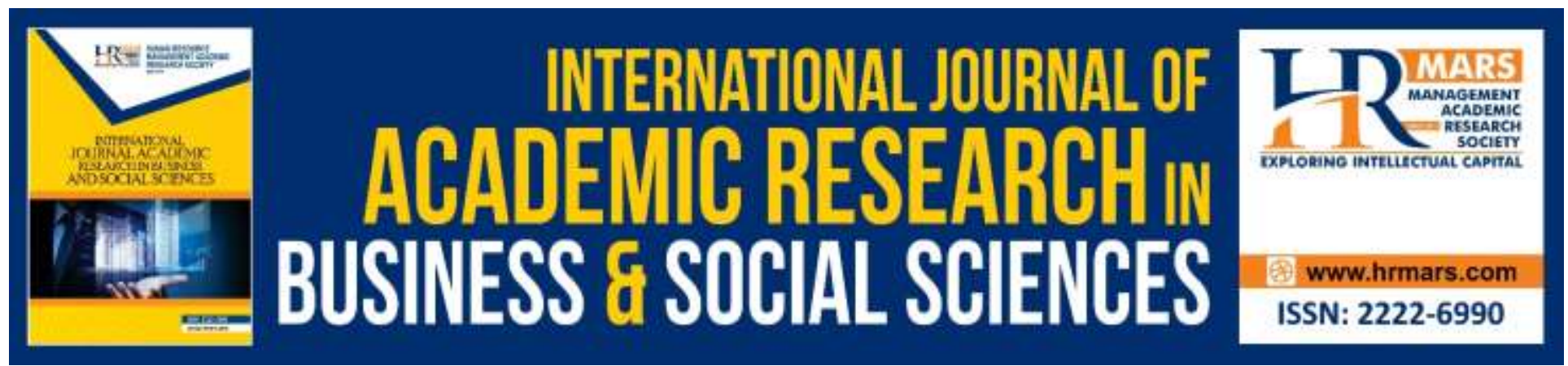

\title{
Chinese Family Business in Malaysia: Development, Culture and the Family Business Philosophy
}

\section{Aissa Mosbah and Kalsom Abd Wahab}

To Link this Article: http://dx.doi.org/10.6007/IJARBSS/v8-i5/4436

DOI:10.6007/IJARBSS/v8-i5/4436

Received: 20 April 2018, Revised: 06 May 2018, Accepted: 21 May 2018

Published Online: 29 May 2018

In-Text Citation: (Mosbah \& Wahab, 2018)

To Cite this Article: Mosbah, A., \& Wahab, K. A. (2018). Chinese Family Business in Malaysia: Development, Culture and the Family Business Philosophy. International Journal of Academic Research in Business and Social Sciences, 8(5), 997-1006.

Copyright: (C) 2018 The Author(s)

Published by Human Resource Management Academic Research Society (www.hrmars.com)

This article is published under the Creative Commons Attribution (CC BY 4.0) license. Anyone may reproduce, distribute, translate and create derivative works of this article (for both commercial and non-commercial purposes), subject to full attribution to the original publication and authors. The full terms of this license may be seen at: http://creativecommons.org/licences/by/4.0/legalcode

Vol. 8, No. 5, May 2018, Pg. 997 - 1006

Full Terms \& Conditions of access and use can be found at http://hrmars.com/index.php/pages/detail/publication-ethics 


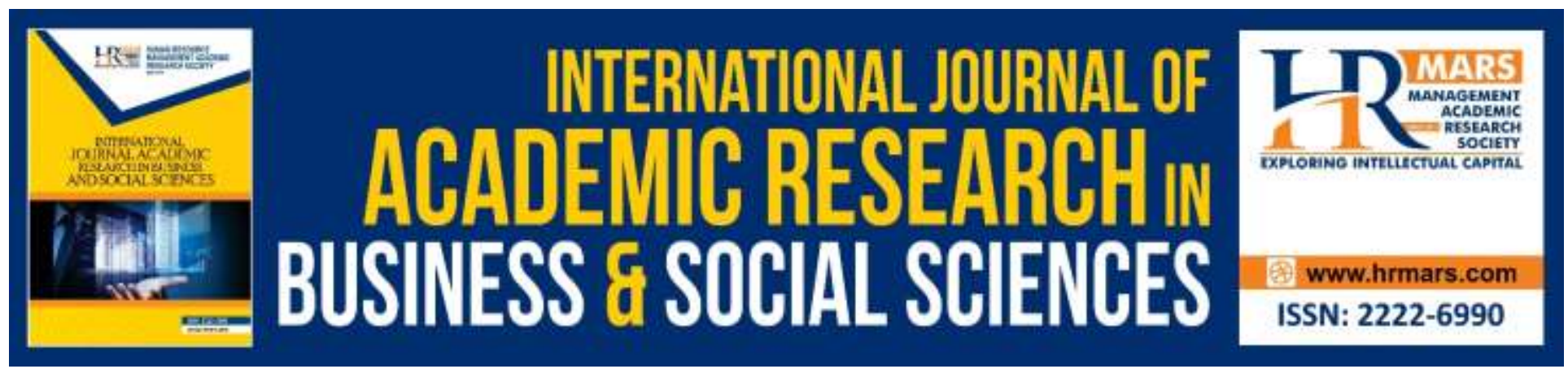

\title{
Chinese Family Business in Malaysia: Development, Culture and the Family Business Philosophy
}

\author{
Aissa Mosbah and Kalsom Abd Wahab \\ Faculty of Economics and Muamalat, University Sains Islam Malaysia.
}

\begin{abstract}
Although there has been an emerging field of research on Chinese family firms recently, the level at which Malaysia Chinese family firms were studied is surprisingly far below the observed realities surrounding this type of businesses including their scope of involvement and achievements. This paper, which is built on the existing literature on the topic of Chinese family firms in Malaysia, discusses the development of these firms and the role of Chinese culture and the family business philosophy in shaping the business identity and influencing much of the business outcomes. The combination of family, intra-ethnic and, most importantly, inter-ethnic networks and partnerships are crucial to the development of the business and account for a good deal of their entrepreneurial experiences. The adoption of western management principles and skills becomes much needed when the business grows larger because traditional Chinese management style that is based on family connections seems to be suitable for small and less complicated firms.
\end{abstract}

Keywords: Chinese, Family, Business, Network, Culture, Malaysia.

\section{Introduction}

Family businesses play important roles in the economies of nations. They generate wealth among family members and may lead to better social ties. In Malaysia, the magnitude and impact of family firms is undeniable. They are the dominant proportion within the Small and Medium-sized sector (Set, 2013; Umrani et al, 2015), and represent about 70\% of the total listed companies (Amran and Ahmad, 2010). Despite observed business engagement of Malays and Indians among other ethnic groups, Chinese family business and Chinese businesses in general are at the forefront since they seize the disproportionately large share of the ethnic business stock. Malaysian Chinese controlled around $65 \%$ of the country total private sector assets and $44 \%$ of the large firms at the beginning of the 21 century (Carney \& GedaJovic, 2002) whereby population representation was only about 23\% in 2018 (Department of Statistics Malaysia website).

Most Chinese firms in Malaysia are family-owned and fall within the SMEs range. This is, in fact, also true for most big Chinese firms which remain under the family control (Ip et al., 2000; Gomez, 
2007). According to Gomez (2007), the government focus, particularly during Mahatir era, shed on developing large firms and the little support granted to SMEs in general did undermined the development and contribution Chinese family firms in terms of outputs and employment. However, this was not an obstacle for them to be established as leading business and economic community in the country. Their operations are characterized by high levels of ownership concentration, cross holdings and significant management control (Goh, 2008). Taking account of the aforementioned reactions, Chinese family firms may have doubled efforts to protect and succeed their business since they are the best option to generate income and sustain economic survivability. This fact, was seen across many East and Southeast Asian where Chinese business groups have been identified as key players in the industrialization and rapid economic growth (carney \& Gedajlovic, 2002). According to a 2018 Forbes magazine website, nine out of the top ten richest businessmen in Malaysia are of Chinese origins.

There exist a considerable number of studies that approaches Chinese diaspora business in South East Asia, however many of them focus on their historical development and inter-ethnic cooperation and discusses their phenomenal growth and success based on cultural attributes and transnationalism (Shapiro et al., 2003; Carney \& Gedajovic 2002; Gomez, 2004; Gomez, 2007). Furthermore, recently there has been an emerging field of research on Chinese family firms particularly in the mainland China, Taiwan, Hong Kong and Singapore (Loy, 2012), but only little evidence was generated. As part of what is observed so far for instance, Chinese family businesses are indigenized in the countries where they are involved and this may have resulted in different business behaviors (Wong, 1993; Zhang and Ma, 2009; Loy, 2012).

In the case of Malaysia, there is a lack of research that deals with the different aspects underpinning this type of businesses (Heng and Ling, 2000; Loy, 2012); a gap that the current study tries to address. Thus, building on a combination of different resources from the literature, the current paper summarizes the findings of the limited literature on the topic of Chinese family firms in Malaysia and traces the development of these firms. The paper also discusses how the Chinese culture and the family business philosophy shape the business identity and leads to success of family SMEs. By doing so, the paper aims to generate updated insights while providing a wider picture of this unique phenomenon.

\section{Previous studies on Chinese family Business in Malaysia}

As highlighted earlier, a few studies have addressed Chinese family firms in the Malaysian context. This is surprising given the fact that these firms are the backbone of the SMEs sector which is in turn pivotal to the economy of the country. The Table below summarizes the findings of nine studies found in the literature. Although only a few, these studies approached Chinese family entrepreneurship from different thematic lenses including development, cultural values, use of networks, management practices, adoption of western management styles and internationalization among others. Similarly, the researchers employed different research types and methods such as empirical quantitative, qualitative, mixed research and case studies. 
INTERNATIONAL JOURNAL OF ACADEMIC RESEARCH IN BUSINESS AND SOCIAL SCIENCES

Vol. 8, No. 5, May 2018, E-ISSN: 2222-6990 @ 2018 HRMARS

Table 1: summary of research findings on Chinese family firms in Malaysia

\begin{tabular}{|c|c|c|}
\hline $\begin{array}{l}\text { Study/ } \\
\text { research } \\
\text { Type }\end{array}$ & Focus & Key findings/highlights \\
\hline $\begin{array}{l}\text { Rutten } \\
(2001) / \\
\text { Discussion }\end{array}$ & $\begin{array}{l}\text { Family business } \\
\text { partnership in the } \\
\text { Muda region (Northern } \\
\text { Malaysia) }\end{array}$ & $\begin{array}{l}\text { Chinese family business owners rely heavily on the } \\
\text { use of kinship ties and the type of relations practice } \\
\text { known as "guanxi" }\end{array}$ \\
\hline $\begin{array}{l}\text { Gomez } \\
(2004) / \\
\text { Discussion }\end{array}$ & $\begin{array}{l}\text { Evolution of Chinese } \\
\text { family firms identity } \\
\text { through use of networks }\end{array}$ & $\begin{array}{l}\text { The intra-ethnic relations and transnational } \\
\text { networks which are anchored in the Confucian } \\
\text { ethics are crucial for capital formation and } \\
\text { accumulation. }\end{array}$ \\
\hline $\begin{array}{l}\text { Gomez } \\
(2007) / \\
\text { Discussion }\end{array}$ & $\begin{array}{l}\text { Development of } \\
\text { Chinese family firms via } \\
\text { an interplay with } \\
\text { transnationalism and } \\
\text { generational change. }\end{array}$ & $\begin{array}{l}\text { These firms have been developing important inter- } \\
\text { ethnic business ties with Malays. Discrimination } \\
\text { generated intra-ethnic competition rather than } \\
\text { cooperation. }\end{array}$ \\
\hline $\begin{array}{l}\text { Nee (2007)/ } \\
\text { Case study }\end{array}$ & $\begin{array}{l}\text { Management style } \\
\text { among Chinese } \\
\text { construction family } \\
\text { firms }\end{array}$ & $\begin{array}{l}\text { Traditional management practices are still followed } \\
\text { while there is also implementation of new skills } \\
\text { gained by the new generation. }\end{array}$ \\
\hline $\begin{array}{l}\text { Goh (2008)/ } \\
\text { Mixed } \\
\text { method }\end{array}$ & $\begin{array}{l}\text { Adequacy and impact of } \\
\text { culture, government } \\
\text { policies and the } \\
\text { corporate governance }\end{array}$ & $\begin{array}{l}\text { The phenomenal success is caused by business } \\
\text { practices stemming from the teachings of I-Ching, } \\
\text { Confucianism and Taoism. The business family } \\
\text { philosophy is changing in the era of globalization. }\end{array}$ \\
\hline $\begin{array}{l}\text { To }(2010) / \\
\text { Mixed } \\
\text { method }\end{array}$ & $\begin{array}{l}\text { The extent to which } \\
\text { successful family firms } \\
\text { adopt Western } \\
\text { management methods }\end{array}$ & $\begin{array}{l}\text { The adoption depends on the company type while } \\
\text { publicly listed firms adopt them more than non- } \\
\text { listed firms. The adoption is also hindered by } \\
\text { Chinese family business characteristics. }\end{array}$ \\
\hline $\begin{array}{l}\text { Abdullah et } \\
\text { al. (2014)/ } \\
\text { Empirical }\end{array}$ & $\begin{array}{l}\text { Business inheritance to } \\
\text { younger Chinese. }\end{array}$ & $\begin{array}{l}\text { Lucrative wages, education, job status, and age are } \\
\text { the main factors impeding young Chinese to } \\
\text { inherent the family business. }\end{array}$ \\
\hline $\begin{array}{l}\text { Cheong et } \\
\text { al. (2015)/ } \\
\text { Case study }\end{array}$ & $\begin{array}{l}\text { The raise and } \\
\text { internationalization of } \\
\text { two family firms. }\end{array}$ & $\begin{array}{l}\text { The state is a major contextual factor for the } \\
\text { internationalization of Chinese family firms }\end{array}$ \\
\hline $\begin{array}{l}\text { Ting (2016)/ } \\
\text { Qualitative }\end{array}$ & $\begin{array}{l}\text { Language choice of } \\
\text { CEOs }\end{array}$ & $\begin{array}{l}\text { Chinese is spoken more than Malay and English. } \\
\text { Language choices are determined by: own language } \\
\text { repertoire, relationship building and as a business } \\
\text { strategy, communication with client's, and absence } \\
\text { of business terms. }\end{array}$ \\
\hline
\end{tabular}


INTERNATIONAL JOURNAL OF ACADEMIC RESEARCH IN BUSINESS AND SOCIAL SCIENCES

Vol. 8, No. 5, May 2018, E-ISSN: 2222-6990 @ 2018 HRMARS

\section{Development}

From early colonial days, Chinese entrepreneurs acted as middlemen for the British, Dutch, and Japanese trading houses (Carney \& GedaJovic, 2002). The tin-mining industry was under their control before Europeans introduced better technologies in the early $20^{\text {th }}$ century. In the early $20^{\text {th }}$ century, they incorporated rubber-production into the economic networks of the gambier and pepper that they had established earlier. However, following the enlargement of rubber plantations, trading and manufacturing competition in the 1930s, they went a step further in their economic advancement and established banks to cater to their financial needs (Whah, 2007). Access to financial capitals and services was also sought from European commercial banks and other communities like Chettiars during the economic depression in the 1920s and 1930s (Suppiah and Raja, 2017). Later, they become strongly dominant over rice mills in the northern region (Wu, 2003) and dominated timber export (Puthucheary, 1979).

However their participation in the manufacturing sector mostly remained small in scale and focused on food, plastic, rubber and wood-based industries due to lack of know-how, capitals and management skills. Notable shift to manufacturing started taking place with the diversification of the financial sector, industry and property development (Wheelwright 1963; Whah, 2007). Worth noting the absence of powerful Malay entrepreneurial class permitted Chinese contractors and developers to play a key role in the construction and property development sector serving in both private and state projects (Whah, 2007). A few family groups emerged as a result including particularly Kouk Group, Hong Leong group, and Tan Chong group. To better understand the development of Chinese family firms in Malaysia, one must pay attention to the ethnic representation and the changing corporate structure in the economy particularly in the post-independence. This era saw the intervention of the government in the economy and the initiation of affirmative actions for the benefit of the majority Malays in acceding government contracts, tender and loans (Rutten, 2001; Gomez, 2007; Whah, 2007; Goh, 2008; Julian and Ahmed, 2008; Chin and Lee, 2012); which led to growing participation of Malays in business life both in terms of firms number and share equity in the corporate sector (Julian \& Ahmed, 2008).

According to Rutten (2001), Whah (2007) and Gomez (2007), The Chinese businesses community responded in a number of reactions which ultimately had multiple bearings on the development of their family firms: 1) shift investment from manufacturing to other sectors like finance, commerce, construction and property development to generate quick returns and escape the Industrial Coordination Act (ICA) requirements, 2) relocate large companies abroad, 3) incorporate influential Bumiputeras and Bumiputera capitals into Chinese businesses, 4) maintain the business paid-up capital just below the required limit to avoid the obligation of offering 30\% equity to Bumiputera shareholders, 5) forge 'Ali-Baba' relationships through which the Malays secure contracts and the Chinese implemented them, and 6) Boycotts like those taking place in the wholesale and retail sector.

While a little is known about the intra-ethnic business networks exploited by Chinese firms (Heng and Ling, 2000), the strategic responses mentioned above include some sort of inter-ethnic business relationships with the local Malays because they represent the majority of the population in the country and dominators of politic scenes. So, in addition to Ali-baba relationships, Inter-ethnic relationships as tapped by Chinese family firms included also: 7) appointing Malays to boards of directors (often with equity but not management) in order to 
INTERNATIONAL JOURNAL OF ACADEMIC RESEARCH IN BUSINESS AND SOCIAL SCIENCES

Vol. 8, No. 5, May 2018, E-ISSN: 2222-6990 @ 2018 HRMARS

help secure access to the state or circumvent bureaucratic red tape consequences in government, and, 8) engaging in business partnerships built on a more equal basis (Jesudason, 1989; Gomez, 2007). This has been reinforced by the attitude of both Malay and Chinese entrepreneurs to forming joint ventures especially for to explore foreign markets (Aziz, 1970). The emergence of a new Malay middle class led to the advent of more equal Sino-Bumiputera partnerships, urged for more listing and gradually reduced intra-ethnic partnerships (Whah, 2007).

Despite arguments claiming that Chinese firms have received little or no support from the government (Whah, 2007) it seems that this is not the case for a good number of large firms. According to (Gomez, 2007) Chinese family firms listed among the largest twenty in Malaysia have all benefited from government patronage, indicating also another face of inter-ethnic ties and perhaps a desire of the government to push value-adding firms that are able to contribute significantly to the economy. Additionally, the Malaysian Chinese Association Chinese (MCA) was another organism that played positive roles in alleviating bureaucratic interference and enhancing growth of family owned firms.

\section{Culture and the Chinese family Business Philosophy}

A dominant school of thought explains the Chinese entrepreneurship phenomenon in light of Chinese culture which is believed to be the principal explanatory tool of the Chinese enterprise dynamism. The concept of culture here relates directly to the Confucian principles that have deep influence on the organizational structure and business practices of Chinese firms (Redding, 1990; Gatfield \& Youssf, 2001; Yan and Sorenson, 2004). Confucian values and norms refer to the ancient set of procedures guiding the social interaction (Yan and Sorenson, 2004).

Whitley (1992) through contrasting the major characteristics of firms and markets in Taiwan and Hong Kong Japan and South Korea characterizes the Chinese business community as the 'Chinese family business'. Chinese follow a strong collective identity and display a unique ethnic style combining family ownership and intra-ethnic business ties. Both have come to exert an influence over business decision-making and development (Heng and Ling, 2000; Gomez, 2004). Family ties and obligations are a core characteristic of the Chinese enterprise (Wong, 1993). In this regard, a link between family business practices and culture must be emphasized when discussing aspect of Chinese family firms.

Factors like strong family connections, resources sharing and pooling, efficient use of labor, thrift culture, use of low gearing and operations flexibility add strength to the small Chinese family firms, but may become a source of the firm weaknesses if it expands (Sin, 1987). A similar argument is advanced for characteristics paternalism, obedience to the manager owner, high centralized decision making and loyalty. These features push performance but may produce difficulties in boosting the future business interests (To, 2010). In fact, the use of kinship ties and guanxi relations are sometime overemphasized (Ruten, 2001). Family support is sometimes as strong as the whole family get ready invest large amounts of money for one member to grab a viable business opportunity on the chance that he may succeed (Hays, 2008).

Another prevalent practice in the Chinese culture is that trust cannot be put on people outside the family. The Chinese are known for distrusting people not belonging to their circle. Similarly, transparency and disclosure do not find their ways in the Chinese family philosophy (Goh, 2008). As such, managers tend to hire people either because the family knows them, or because they 
are introduced by some members of the family (Fukuyama, 1995; Hays, 2008). While the notion of trust contributes in many ways to the firm betterment, it may have reverse implications on the business prospects as it would not be useful when the business grows bigger.

It is perhaps because of this idea that the Chinese family system is arguably said to be effective in simple organizations but is not well effective in sophisticated and high-tech organizations that require complicated processes and spend hugely on research and development and design (Hays, 2008). Carney (1998) adds in this contest that success of Chinese family businesses is attributed to the relatively simple 'personally managed' organizations that are operationally contained in a network of kin and ethnic ties.

While these practices and the Confucian principles in general adapts well to the management style that is based on hierarchies, their advantages translate into maintaining the management size down and allowing decisions to be made faster without lengthy meetings. This in turn enables firms to move rapidly into profitable markets. Redding (1990) argued in the same course that the Chinese family business is peculiarly effective and among the reasons of the East Asia economic miracles. The drawbacks of this system on the other hand are that favoritism puts possible talents out and family conflicts can divide a company especially after the death of the patriarch (Hays, 2008).

New patterns associated with the management, outcomes and consequences of Chinese businesses in Malaysia have emerged in the last decades owing to the enlargement of these businesses together with the tendency towards the adoption of western management styles. The advent of the globalization era and the need for advanced technology products, services, capital and expertise from outside the family circle have also pressured for such change in the Chinese family business philosophy (Goh, 2008). The following patterns are identified: First, many Chinese companies are controlled by old patriarchs and assisted by Western-educated family members (Hays, 2008). The findings of Nee (2007) on the Chinese family firms in the construction pointed to the use of both traditional Chinese management practices and modem management skill by the new generation members.

Second, Generational change threatens the survival of family firms. Evidence points to the fact that descendants in the family SMEs in Malaysia refuse joining the family firm, which ends up closed down or sold off. Reluctance to join the family business is due to perceptions that SMEs career is perceived as a life of drudgery. Most parents feel the same way and want their children to become professionals. In many other cases, there is announced tendencies towards recruiting professional managers because they have better education or skills needed to develop the firm or because they have better abilities to work with non-Chinese (Gomez, 2007). Under these conditions therefore, it is not surprising to see owners preferring that their children become professionals rather than being involved on the businesses (Hing and Ping, 2001).

\section{Conclusion}

This paper built on the existing literature on the topic of Chinese family firms in Malaysia to discuss the development of these firms and the role of Chinese culture and the family business philosophy in shaping the business identity and leading to success of family SMEs. Surprisingly, the level at which Malaysia Chinese family firms were studied is far below their scope and achievement. In fact the success of Chinese firms is found across the whole South East Asian 
region. They controlled more than $70 \%$ of the corporate wealth in 1995 although they totaled only $6 \%$ of the population in the region (Backman, 1995).

The combination of family, intra-ethnic and, most importantly, inter-ethnic networks and partnership shapes business experiences and account for a good deal of their success and growth. The adoption of western management principles and skills becomes are much needed when the business grow large because traditional Chinese management style that is based on family connections seems to be suitable for small and less complicated firms. Perhaps because of the unprecedented levels of growth and adoption of western management approaches that Carney (1998) suggested that the western theory of the family firm provides a substitute explanation for investment strategies and organizational structure.

\section{References}

Abdullah, I. H. T., Azmi, M. S., Zin, S. M., Chee, L. S., \& Yusoff, N. A. (2014). Interaction between Chinese family business and cultural differences in Malaysia. Asian Social Science, 10(10), 118.

Amran, N. F., and Ahmad, A. C. (2010). Family succession and firm performance among Malaysian companies. International Journal of Business and Social Science 1(2), 193-203.

Aziz, A. M. (1970). Malay management practices and problems in international trade. Kuala Lumpur: Unit Penyelidikan Sosioekonomi.

Backman, M. (1995). Overseas Chinese business networks in Asia. Sydney, Australia: DFAT East Asia Analytical Unit.

Carney, M. (1998). A management capacity constraint? Obstacles to the development of the overseas Chinese family business. Asia Pacific journal of management, 15(2), 137-162.

Carney, M., \& Gedajlovic, E. (2002). The co-evolution of institutional environments and organizational strategies: The rise of family business groups in the ASEAN region. Organization studies, 23(1), 1-29.

Cheong, K. C., Lee, P. P., \& Lee, K. H. (2015). The internationalization of family firms: case histories of two Chinese overseas family firms. Business History, 57(6), 841-861.

Fukuyama, F. (1995). Trust: The social virtues and the creation of prosperity, Free Press Paperbacks.

Gatfield, T., \& Youseff, M. (2001). A critical examination of and reflection on the Chinese family business unit and the Chinese business clan. Family Business Review, 14(2), 153-158.

Goh, K. S. (2008). Corporate governance practices of Malaysian Chinese family owned business. Phd Thesis, Southern Cross University.

Gomez, E. T., \& Benton, G. (2004). Introduction: De-essentializing capitalism: Chinese enterprise, transnationalism, and identity. In Chinese Enterprise, Transnationalism and Identity (pp. 17-36). Routledge.

Gomez, E. T. (2007). Family firms, transnationalism and generational change: Chinese enterprise in Britain and Malaysia. East Asia, 24(2), 153-172.

Hays, J. (2008). Chinese in Malaysia, retrieved from: http://factsanddetails.com/southeastasia/Malaysia/sub5_4c/entry-3645.html

Heng P. K., and Ling, S. L. (2000). The Chinese Business Community in Peninsular Malaysia, 1957-1999," in Lee Kam Hing and Tan Chee Beng, (eds) the Chinese in Malaysia Shah Alam: Oxford University Press. 
INTERNATIONAL JOURNAL OF ACADEMIC RESEARCH IN BUSINESS AND SOCIAL SCIENCES

Vol. 8, No. 5, May 2018, E-ISSN: 2222-6990 @ 2018 HRMARS

Ip, D., Lever-Tracy, C., \& Tracy, N. (2000). Chinese business and the Asian crisis. Aldershot, England: Gower Publishing

Jesudason, J. V. (1989). Ethnicity and the Economy: The State, Chinese Business and Multinationals in Malaysia, Singapore: Oxford University Press.

Julian, C. C., \& Ahmed, Z. U. (2009). Doing business in Malaysia. Thunderbird International Business Review, 51(1), 53-69.

Hing, L. K., and Ping, L. P. (2001). The 1997 Asian Financial Crisis, Chinese Business and Corporate Development in Malaysia". Paper presented at the conference on "Chinese Business and Culture in Local and Global Contexts," Academia Sinica, 15-16 February, Taipei, Taiwan.

Loy, T. J. (2012). Overseas Chinese family business research: a comparative analysis. Journal of family business management, 2(1), 31-39.

Nee, O. H. (2007). An Assessment of New Management Style of Chinese Family Construction Related Company, Master thesis, University Sains Islam Malaysia.

Puthucheary, J. J. (1979). Ownership and Control in the Malayan Economy. Kuala Lumpur: University of Malaya Cooperative Press.

Redding, G. (1990). The spirit of Chinese capitalism (Vol. 22). DeGruyter.

Rutten, M. (2001). Family enterprises and business partnerships: Rural entrepreneurs in India, Malaysia, and Indonesia. The Journal of Entrepreneurship, 10(2), 165-189.

Set, K. (2013). Tourism Small and Medium Enterprises (TSMEs) in Malaysia." International Journal of Business and Social Science, 16(4), 58-66.

Shapiro, D. M., Gedajlovic, E., \& Erdener, C. (2003). The Chinese family firm as a multinational enterprise. The International Journal of Organizational Analysis, 11(2), 105-122.

Sin, G. T. (1987). The management of Chinese small-business enterprises in Malaysia. Asia Pacific Journal of Management, 4(3), 178-186.

Suppiah, U., \& Raja, S. S. (2017). Chettiar capital and the emergence of the Chinese bourgeois in British Malaya. Kajian Malaysia: Journal of Malaysian Studies, 35(1), 1-21.

Ting, S. H. (2017). Language choices of CEOs of Chinese family business in Sarawak, Malaysia. Journal of Multilingual and Multicultural Development, 38(4), 360-371.

To, B. (2010). The adoption of western management methods by Chinese family and publicly listed companies in Asia (Doctoral dissertation, Middlesex University).

Umrani, A. (2015). Corporate Governance Practices and Problems Faced By SMEs in Malaysia, Global Business and Management Research: An International Journal, 7(2).: 71-77.

Whah, C. Y. (2007). From tin to Ali Baba's gold: the evolution of Chinese entrepreneurship in Malaysia, IIAS Newsletter, 45, 18, Leiden nversity repository, available at: https://openaccess.leidenuniv.nl/handle/1887/12815

Wheelwright, E. L. (1963). 'Reflection on Some Problems of Industrial Development in Malaya'. MER 8-3.

Wong, S. L. (1993). The Chinese family firm: A model. Family Business Review, 6(3), 327-340.

Wu, X. A. (2003). Chinese Business in the Making of a Malay State, 1882-1941: Kedah and Penang. London: Routledge Curzon.

Yan, J., \& Sorenson, R. L. (2004). The influence of Confucian ideology on conflict in Chinese family business. International journal of cross cultural management, 4(1), 5-17. 
INTERNATIONAL JOURNAL OF ACADEMIC RESEARCH IN BUSINESS AND SOCIAL SCIENCES

Vol. 8, No. 5, May 2018, E-ISSN: 2222-6990 @ 2018 HRMARS

Zhang, J., and Ma, H. (2009). Adoption of professional management in Chinese family business: A multilevel analysis of impetuses and impediments, Asia Pacific Journal of Management, 26(1): 119-139. 